iolses

\title{
Exploring Experiences of Two Hourly-Paid Teachers at Public Schools: A Narrative - Biographical Study
}

\section{Research Article}

\author{
Yunus Emre OMUR', Bunyamin BAVLI² \\ ${ }^{1}$ Yildiz Technical University, Faculty of Education, Department of Educational Science, Istanbul, Turkey, ORCID: 0000-0002-1535-3461 \\ 2 Yildiz Technical University, Faculty of Education, Department of Educational Science, Istanbul, Turkey, ORCID: 0000-0002-7274-0935
}

To cite this article: Omur, Y. E., \& Bavli, B. (2021). Exploring experiences of two hourly-paid teachers at public schools: A narrative - biographical study, International Online Journal of Educational Sciences, 13(1), 141-159.

\begin{abstract}
ARTICLE INFO
ABSTRACT

Article History:

In Turkey, employing hourly-paid teachers under precarious conditions has been adopted by the Ministry of National Education (MoNE) to solve teacher shortage at public schools for a long time.

Received: 09.07.2020 However, this type of employment involves challenges and disadvantages for hourly-paid teachers. The literature includes various studies and findings regarding to hourly-paid teacher employment

Available online: and the status of teachers. Although the issue of hourly-paid teaching was examined in depth by

21.01.2021 adopting qualitative approaches, it was not addressed using the narrative approach with the participation of individuals with long-term hourly-paid teaching experience. Current study aims to narrate the experiences of hourly- paid teachers teaching at the public elementary schools for 15-20 years. Narrative Biographical Approach was operated in the study to reveal how two hourly- paid teachers serving at the elementary level at the two separate public schools comprised their life stories regarding hourly- paid teaching. To obtain participants of the study, researchers employed snowball sampling which is one of purposeful sampling techniques managed in the qualitative studies. As the researchers intended to relate past and the present to reconstitute the life stories of the participants, Biographical Narrative Interview (BNI) method operated during the interviews to collect data in the study. To achieve interpretation of the obtained data and define how reality is formed by each participant, narrative analysis was executed. Findings of the study revealed that choose of the hourlypaid teaching is a result of unemployment and economic conditions. During hourly-paid teaching, teachers experience social, economic, psychological and professional challenges such as discrimination, salary deduction, drudgery, personal rights restrictions. The study clearly presented that despite the challenges experienced, inner and altruistic motivation are the key instruments to conduct the hourly-paid teaching.
\end{abstract}

(C) 2021 IOJES. All rights reserved

Keywords:

Teacher Employment, Hourly-Paid Teaching, Narrative, Biographical Study

${ }^{1}$ Corresponding author's address: Y1ldiz Technical University

Telephone: +902123835568

e-mail: yunus.emre.omur@gmail.com

DOI: https://doi.org/10.15345/iojes.2021.01.009 


\section{Introduction}

According to neoliberal principles, unrestricted markets are the most efficient mechanisms for allocating resources, optimizing outcomes, and ensuring efficiency and productivity. Neoliberals advocate removing any regulations on markets, privatize state functions, dismantle any collective bargaining structure, and abandon the welfare state rationality. This transformation from the welfare state to the neoliberal market economy has been taking place in Turkey since the 1980's. As a result, for the last forty years, neoliberal economic principles have dominated employment relations in job markets, and flexibility has become the hallmark of neoliberal employment patterns.

Atypical employment which does not conform to the standards of full-time, regular, open-ended employment with a single employer over a long time provides employers with the ability to hire and fire employees as needed and to reward workers on an individual rather than collective basis have come to be regarded as pivotal to maximizing profits, creativity, productivity, and economic growth (Crowley \& Hodson, 2014). According to Standing (2011), this is a process of labor re-commodification, making the labor relationship more responsive to demand and supply, as measured by its price, the wage, which has meant eroding all forms of security that the welfare state used to provide to individuals. Flexible employment which is characterized by low wage, short term contracts, and lack of social and employment security bring along a precarious life. Standing (2011) asserts that the number of individuals working without social security under flexible conditions has risen and these insecure individuals make up what he calls the precariat, a new dangerous class.

In Turkey, education is both public and private funding; however, it is mostly public. The school system is centralized with lack of school and local authority (Schleicher, 2018). Decisions regarding to budget, curriculum, hiring, and dismissing of teachers at public schools from pre-primary to upper-secondary schools are made by the Ministry of National Education (MoNE) centrally. In addition to that, textbooks are provided free of charge to students and teachers from pre-primary to upper-secondary schools by MoNE all around the country. Following undergraduate education, teachers at the public school are hired by MoNE centrally depending on the written and oral exams on content knowledge, pedagogical knowledge, general ability, and general knowledge. The teaching profession is guaranteed by the basic law of national education. The teacher in the relevant law is defined as "the person who is an expert and who performs the duties regarding education and administration assigned by the state" (Ministry of National Education, 1973).

In Turkey, the precariat includes the teaching profession, once regarded as a safe harbor of social security, and even public schools employ some of their teachers under flexible conditions (Günerigök \& Oğur, 2018; Orakc1, 2015; Sağıroğlu, 2013). Most of the teachers in Turkey are appointed centrally by the Ministry of National Education (MoNE) with employment security and a decent wage. Teachers are employed with contractual status in the first four years of teaching and then depending on their performance they work as a permanent civil servant officer. However, due to budgetary considerations, the number of teachers newly appointed every year does not meet the teacher need of MoNE. In this case, MoNE authorizes local education administrations to employ hourly-paid teachers at the schools that need extra teachers. At the local level, with the coordination of the district directorate of national education, when a sufficient number of teachers are not appointed centrally by the MoNE, the school administration employs hourly-paid teachers to meet teacher shortage. However, hourly-paid teacher employment poses some challenges. Some of the challenges sourced from the kind of employment and its results. Though, hourly-paid teachers are called teachers, it is not necessary to have a degree on teaching to be an hourly-paid teacher. It is obvious that, some of the hourlypaid teachers, actively teaching at public schools with their colleagues who are faculty of education graduates or faculty of science and arts graduates but have pedagogical formation certificates, do not have the necessary knowledge of general pedagogical knowledge, pedagogical content knowledge, or even content knowledge. 
When recent practices regarding the employment of hourly-paid teachers have been examined, it is observed that hourly-paid teachers with associate degrees are employed as well (Ministry of National Education, 2020). In addition to that, hourly- paid teachers experience various challenges during teaching. This issue addressed in many studies in many ways (Çınkır \& Kurum, 2017; Güvercin, 2014; Öğülmüş, Yildirim, \& Aslan, 2013; Polat, 2013; Tuncer, 2012) however, few studies focus on the issue of hourly- paid teaching in a narrative way as the nature of the hourly-paid teaching is short and temporary. The current study aims to narrate the experiences of hourly- paid teachers teaching at the public elementary school for a long time.

\section{Methodology}

\section{Design}

As the current study aimed at discovering the personal experiences regarding teaching as a paid teacher, the qualitative research design was executed. Even though, the qualitative design intends to acquire in-depth data to understand personal perspectives and interpret phenomena, the purpose and scope of each qualitative research approach vary (Merriam, 2002). While some qualitative research approaches involve more people to discuss and obtain reach data, some others such as narrative focus on few people possessing deep and comprehensive data based on long-term experience. It is considered by the researcher that narrative design is the most suitable. In line with this purpose, narrative research methodology was adopted in the current study to reveal how two hourly-paid teachers serving at the elementary level at the two separate public schools comprised their life stories regarding hourly-paid teaching. Narrative research concentrates on how individuals experience the world (Connelly \& Clandinin, 1990). Narrative research accesses individual stories as data and reorders it chronologically (Creswell, 2012). Narrative research not only requires the researcher to gather personal stories but also redescribe the story to generate meaning in an analytical interpretive way (Mishler, 1995). The narrative includes various approaches such as biographical, autoethnography, life history, and oral history approach. As the current study does not cover the entire life of the participants, data gathering and recording were conducted by the researchers, biographical approach, which is a strong appropriate instrument to conceive multifaceted processes, operated in the study (Creswell, 2012; Kelchtermans, 1993).

\section{Participants of the Study}

Sampling is mainly related to the research problem and research questions (Creswell, 2012). As the current study is qualitative in nature, researchers employed nonprobability sampling, covering purposeful sampling techniques, to choose participants of the current study (Patton, 1990). To select and reach study participants, the researcher first of all sought for the persons suitable for the study. For this purpose, the researcher informed school principals, teachers, graduate, and post graduate students about the study and characteristics of the participants. At the end, the researcher obtained the first participant at a public school where researchers conducted focus group interviews with the teachers for a previous study. This 44-year-old, female participant has a double degree, Tourist Guiding, Turkish Language and Literature. She has been teaching English as a paid teacher at a public elementary school located in the rural part of Istanbul for 20 years. The researcher accessed the second participant via post-graduate student, who is also a kindergarten teacher at a public school, taking Masters of Art courses from one of the researchers. This 38-year-old, male participant has degree on Chemistry. He has been teaching Science as an hourly- paid teacher at a public elementary school located in the rural part of Istanbul for 14 years. Before conducting interviews with the participants, researchers first of all informed participants about the purpose and scope of the study. As the interview was conducted before the Covid-19 Pandemic with the first participant, the researcher got the opportunity to inform the participant about the study and conduct face-to-face interviews. However, the interview with the second participant was conducted during the Covid-19 Pandemic. The researcher informed the participant via e mail and conducted an online interview via Zoom program. In each interview, face-toface and online, the researcher conducted the interviews at the appropriate date and time for the participants. 


\section{Data Collection and Interpretation}

Qualitative collection methods in qualitative studies include interviews, documents, observations to acquire verbal, nonverbal data such as feelings, gestures, and interactions (Yin, 2017). Interview, involving asking questions to an individual or a group in a subject matter, is the most adopted data collection method in qualitative research (Bryman, 2016). As the nature of the current study required the researcher to comprehend personal perspective and interpret phenomena, the researcher employed semi-structured interviews with the participants. Semi-structured interview including open-ended and general questions allowed the researchers to ask extra questions depending on the responses of the participants (Bryman, 2016). In addition to that, as the researchers intended to relate past and the present to reconstitute the life story, Biographical Narrative Interview (BNI) method operated during the interviews. Within this respect, researchers first asked a general question, and then depending on the respond of the participants, researchers raised the second nondirective questions to obtain biographical data. In this manner, participants had the opportunity to relate past practices and experience with the current practices and life. In addition to that, researchers also operated follow-up questions during the interviews to motivate and maintain narration of the participants. Researchers also employed "Why" and "How" questions for clarification and association (Rosenthal, 2004).

To achieve interpretation of the obtained data and define how reality is formed by each participant, narrative analysis was executed in the study. Narrative analysis is an effort to form a meaningful whole via sequencing, arranging, interrelating the story provided by the participants. Models of narrative analysis cover thematic analysis, structural analysis, interactional analysis and performative analysis. The thematic analysis focuses on the presented data rather than the way of presenting it and follows an inductive way (Reissman, 1993). To achieve thematic analysis, the researchers, first of all, took memos during each interview. Following the interviews, both of the researchers transcribed each interview and had the opportunity to comprehend data. Following the transcription process, each researcher conducted thematic analysis separately and discuss the obtained codes, categories, and themes (Saldaña, 2012).

\section{Validity and Reliability}

The philosophy on which qualitative research is based differs from quantitative research. This distinction in paradigms constitutes a variation in the concepts and terms adopted in qualitative research. Validity in quantitative research corresponds to trustworthiness in qualitative research and reliability in quantitative research corresponds to consistency in qualitative research. In qualitative research credibility, transferability, dependability, and confirmability are managed for the trustworthiness and consistency of the study (Golafshani, 2003). To ensure trustworthiness and consistency in the study, the researcher operated various instruments during the study. In this respect, following the transcription of each interview researcher obtained a member-check from each participant to validate transcription. The researchers also executed peer debriefing techniques to assure credibility in the study. As the study is joint in nature, it provided the researchers the opportunity to review and assess the transcriptions, data analysis, and the whole paper concurringly (Lincoln \& Guba, 1985). Furthermore, researchers also acquired expert reviews to assess the data interpretation process and obtained categories and themes. A qualitative study also requires selecting proper cases or participants. To select proper participants in the study, researchers conducted pre-interview, face to face and via phone calls, with each participant before the interviews to define their eligibility and obtain their consent (Huberman, Miles, \& Saldana, 2013).

\section{Ethical Considerations}

Ethical issues are integral in research. It is especially substantial in qualitative research as the researcher is a part of the study. To ensure ethics in the study, researchers have taken some precautions. With this purpose 
in mind, each participant was informed by the researchers beforehand of the interviews. Researcher provided information about the role and responsibilities of the researchers, nature, purpose, and scope of the study, potential impacts of the study via face to face meetings and phone calls. In addition to that, the researcher provided the opportunity to the participants to ask questions about the study. Following a brief preliminary informal interview and getting the consent of the participants, the researcher and participants decided on the place, data and time of the interviews. On the day of the interview, researcher informed participants about the rights, confidentiality, and use of the obtained data via consent forms. The researcher ensured the participants to protect the privacy of the participants and not to reveal personal information. Hence, the current study only covers the demographic information about the participants such as age, gender, experience, expertise, level, and type of the school. However, real names, school names, and exact locations of the participants are excluded in the study. Instead of real names, the researchers employed pseudonyms for each participant.

\section{Findings}

\section{First Years}

Feride is 44 years old, and has been teaching for 22 years. What makes Feride the focus of this study is that she has been teaching for 22 years under the conditions of hourly-paid teaching. In advance of receiving both Turkish Language and Literature and Tourism Guidance training at the undergraduate level, Feride graduated from the chemistry department of the vocational high school before and started to work as an hourly-paid teacher after her secondary education.

Sinan, on the other hand, graduated from the Faculty of Arts and Sciences, Department of Chemistry in 2001. Since 2005, he has been teaching as an hourly-paid teacher along with other different jobs. He taught chemistry in a high school in the first 4 years of his career as an hourly-paid teacher, and then started as a science teacher at the school where he has been currently working.

Feride, who is an English teacher now, started teaching as a classroom teacher. After working as a classroom teacher for 6 years, Feride worked as a Turkish teacher for 3 years before she took a break from teaching to obtain her undergraduate degree for a while. After completing her education in tourism guidance, Feride continued to teach instead of doing her profession, and has continued to teach English since 2005. Feride's start as an hourly-paid teacher came out of necessity rather than a conscious choice. Feride expressed her story of turning to hourly-paid teaching due to the coefficient barrier she encountered due to being a vocational high school graduate and the situation of the labor market in that period as below:

We had a vocational high school graduate coefficient issue. For many years, that is why I could not enter any faculty of education, including chemistry teaching. Later, when the coefficient issue was resolved, I wanted to retake the exam and try my luck. My goal was to enter the English Language Teaching department at that time, but my misfortune was over that year, too. [...] I was looking for a lab job on chemistry. I told a few people that I was looking for a job, in case they hear anything. Luckily, again, whether I should say it is my misfortune, or whether I am unlucky, there were some points where I narrowly missed some things at the last minute. Just when I was looking for a job, Lüleburgaz and Çerkezköy Organized Industrial Zones were established in Kocaeli and most of the factories that I could work moved there. Options here were reduced. My family did not want me to work at a paint factory, and so on. Meanwhile, this came out to me. Hourly-paid teaching came out. After high school, I graduated from a technical high school. I graduated with the title of a technician. I did not want to study at the post-secondary level. Because my job title would not change. As I said, when I started teaching, I could not think of anything other than teaching. It continued today as I was stuck with the coefficient issue.

As it can be understood from the above statements, Feride, when she was graduated from high school, considered teaching as a temporary solution, as a result of both the economic conditions and the practices of 
the education system at that time. Feride, who started working as an hourly-paid teacher until she found a better job in cases where even the conditions of permanent teaching were insufficient, used the following statements to indicate this situation:

I did not apply for paid teaching, so it happened to me by chance. I was 19 years old. To be honest, I never thought about it. I couldn't accept it at the first moment due to its circumstances. How much could it be done under these conditions?

Sinan's choosing hourly-paid teaching was due to reasons similar to Feride's. Facing unemployed at the time when he was graduated from the university, Sinan chose hourly-paid teaching because of economic considerations. On the other hand, unlike Feride, Sinan chose hourly-paid teaching as it allowed him to do additional work. Sinan narrated how he chose hourly-paid teaching as below:

I tried other jobs in the first years. I was in Diyarbakur at that time. They also wanted experience to enter that industry. I thought it would be difficult. Also, I had to work in different provinces. That's why I didn't demand much. It was not easy to find a job in Turkey. When I tried to work in the private teaching institutions, they made me work until eleven at night and I could not get any reward for my labor. In hourly-paid teaching, for example, I have a lesson from eight to twelve in the morning. After that, this job was a little more attractive to me as there was an opportunity to find an additional job. Otherwise, there is no economic gain. It also gave me some time to do additional work. I also tried various institutions. At that time, I worked in private teaching institutions. When I just graduated, I worked as an intern before starting hourly-paid teaching. I have also worked for various marketing firms, but in the end, this was more attractive. In addition, I tried to do additional work and continue my life.

Feride, who started working as an hourly-paid teacher as a temporary job, had an emotional connection with the teaching profession from her first years, despite negative conditions stemming from her status. Shortly after starting hourly-paid teaching, she refused the more attractive job offers and continued to teach. It is understood from the following statements of Feride that what made her refuse those opportunities was the strong bond she built with her students and her profession:

It didn't make much sense before it started. In fact, I was looking for a job and when hourly-paid teaching prompted, I said I could not do it, I couldn't deal with children. But I can say that it has become my life later. I actually started as a temporary job. But then I couldn't quit when I got involved. Although I encountered other job opportunities, I could not quit teaching. I have a life as a teacher and I really love it. I cannot think of myself in any other job. It has been like this since the moment I started, so I couldn't think of myself in another job. The person who proposed this job said that he would find me another job after one month. He said "handle it". The jobs he found later perhaps presented better opportunities, but I did not accept it, I continued and I came to the point of not leaving my students. I have been teaching since then.

Like Feride, Sinan has been working at the same school for the last 11 years as a science teacher. In addition to the fact that the school he has been teaching is near to his other jobs, what let Sinan do hourly-paid teaching for 11 years is the immaterial satisfaction he gets from the teaching profession. Shat Sinan narrated at this point is as follows:

The main reason for me to continue is that I worked at the same school. Since I am from the east of Turkey myself, I communicated better with those people and the parents there. They loved me. We even visited all parents in that area within the scope of my guest project. We visited nearly a hundred families. I was loved there. I mean, I stayed because I reached that professional satisfaction. I left the financial side of the job aside, and I took care of my students and continued when I got his pleasure. Since my extra work was also in that area, that area was a little more attractive for me. I didn't want to quit. As a profile, they were generally families who migrated from the eastern cities of Turkey. They were always problematic students. 
I understood their language. Since these children came due to immigration, they were doing things like bad habits, drug dealing and snatching in that area. I visited their families. When I visited their families, the students developed a sense of respect for me.

The strong bond Feride constructed with her students and profession was not enough for her to overcome difficulties arising from her being inexperienced and lacking a formal education. She narrated the first moment she entered a classroom as a high school graduate as follows:

I was 18 years old. There was a school in Sultançiftliği district. At that time, transportation was not the same as it is now. I called the manager, got the address and went to school. I never forget the first day. The vice principal... Why did he do such a thing? Now, for example, our principals would not do such a thing. He took me, I am 18 years old, he said, I would enter the fifth grade. I had no experience with teaching. I knew no terms, no concept, nothing. I mean, I didn't know what the annual plan, the daily plan, or whatever. I had graduated from the chemistry department of high school. He left me in front of the class. He told to me to introduce myself and start. I opened the door. There was a teacher in front of the blackboard. I intended to go back. When he turned his face to me, I noticed that he was wearing a plaid jacket and a blue apron. There was a student taller than me in front of the blackboard. He was 15 years old then. He was a 5th grader. You know, it is Sultançiftliği district. It was a 63-person classroom. I thought he was a teacher and I got excited. I did not know how to behave at first, and then I gathered myself when I saw the apron and realized that he was a student. Anyway, I introduced my and started, of course, it was a great excitement. First of all, I was only 3-4 years older than the student at the board. At first, he resisted a little, but then somehow I managed to get to him.

As it is understood from Feride's statements above, she entered the profession while she lacked both experience and knowledge. Furthermore, as there was a small age difference between her and her students, Feride's first years in teaching were a process of learning and gaining experience. In this process, the most important learning source for her was more other experienced teachers. In addition, the development of information technologies also provided Feride with the opportunity to develop her teaching skills. In short, the professional learning process of Feride, who took the first step into the profession without any teacher training, was realized at work with the support of her colleagues. Feride narrated this point as follows:

At that time, I wondered if I could do what I had to do. But there were other teachers like me where I worked. Maybe because we formed a group, it did not reflect much. Permanent teachers were very helpful. For example, I had a friend who sat down and told me how to write a daily plan all day. At first, I didn't know anything. In other words, as a student we see from outside, the teacher comes, he teaches his lesson, he assesses it, and he goes out. I didn't know how to prepare an annual plan. At that time, it wasn't just like now. Now, we print the plan, put it in our file, and check that plan throughout the year. We had daily plan notebooks then. Thanks, my friends helped me. Of course, I had a hard time for the first few weeks, but then I had the best daily plans for example. I even used to write what kind of questions or figures I would use in the class. I learned quickly. I was sitting and dealing with the plans for hours every evening. Of course, I learned these slowly. And then, as the technology developed, e-school came into play and many things changed. In the early days, it was a notepad, a slip sheet, sheets, and so on. All of these are now on the computer. I had such difficulties at first, but it was also enjoyable though. We were gathering together during the report card period. One of us said, one of us wrote and we were doing our works together.

Although he started teaching with an undergraduate degree, Sinan too did not have any education on the teaching profession. Consequently, Sinan resolved his lack of theoretical education with the experience he gained over the years and gained knowledge related to the teaching profession with his own efforts. He narrated how he gained this experience as follows: 
You improve yourself in the process. So if there are one hundred and fifty students to take the exam, at most seven of them will enter somewhere. As a teacher, you can feel this. You train yourselfaccordingly. Students do not know anything. In all aspects, science is my branch, but I taught Turkish, as well. I taught math, as well. Social studies also ... As we were constantly preparing for KPSS (public personnel selection examination), we were well-trained on these issues. For the benefit of the students... That is how we were training ourselves. Now the newly appointed teachers come and get my advice. How shall we do it? Or how can we do it if we are going to a parent meeting. I am going with most of the teachers. In that way, since you are dealing with problematic students in the process, you are using methods that are not necessarily written in books. This improves you professionally.

\section{Hourly-Paid Teaching as a Precarious Job}

Although both Feride and Sinan stated that they taught in passion, they have also been experiencing some disadvantages stemming from the employment conditions of hourly-paid teaching. First of these disadvantages is temporary employment status, one of the characteristics of hourly-paid teaching. Possibilities such as the appointment of a permanent teacher during the academic year, not being able to work at the same school in the next year, or not being able to work as an hourly-paid teacher in any way were factors that constantly disturbed both Feride and Sinan. As it can be understood from their statement below, Feride and Sinan experience stress because of the temporary employment status:

There is no guarantee. That thing is always on one side of my head. That uneasiness is always on one side of my head. Where will I be next year? Okay, there is a chance that I will teaching here, but the possibility is uneasy, even if it is one percent. If I'm here next year, I'll get the eighth graders. I start my sentence like that, for example, they say, where will you be. Sure you'll be here, where else will you be? There is no guarantee. If they gave me such a guarantee, for example, I would be at this school for 10 years. As if that uneasiness will be erased and there will be no more. That's why from time to time I searched for another job. The whole thing is still going on well. But, where will I be next year? This year is over, but will I be here next year? I have been here for 7 years. I worked at my previous school for 8 years, that is, without interruption. The most tiring thing for me is this question: "Where will I be next year?" You are a teacher today, you are giving the report card. Then you are unemployed the next day. I have such a situation. This is a little tiring for me. (Feride)

Imagine I am lucky in that, but every year hourly-paid teachers are in a different school. Wherever there is a teacher shortage, they throw us there. No matter how hard you have worked, when you go to a new place, you find your place odd. The process of meeting with students, the process of getting used to those students... All of these affect your motivation. Actually, even if you are a very, very successful teacher. In fact, there are chances you may go to several schools in the same year. You have no motivation left. (Sinan)

Besides the fact that they are employed temporarily, another disadvantage of hourly-paid teaching is that the amount they earn, which is below the minimum wage, is not enough to live a decent life. Feride and Sinan narrated the economic hardship they had been experiencing as follows:

The salary we receive may seem higher than it used to be, but its value is not the same as before. Although I am not supporting a family, I hardly survide one month. Of course, I have to give up many things financially. We calculate constantly. I am not married. I am not the breadwinner. In this sense, nothing compels me. Would it be bad though? No. We do the same job with permanent teachers. I am doing more than some of them, I know that there are those who do not work, cannot work, or are not as efficient as I do, although they are permanent. I've witnessed it over time. I would also like to get the exact value for this. For example, I do the same job, maybe I do more, and he gets three times more salary than me during the 
year. Even if we divide this into three months when the school is closed due to the summer holiday, my salary actually decreases even more. (Feride)

We are currently working for one third of the permanent staff. In fact, it's now a quarter of the price. We have been working on this for many years. When there is a holiday, when there is a snow holiday or when there is a public holiday, we are immediately charged. In other words, there is no money you get in return. We don't even get the minimum wage. Immediately recognized that we earned different amounts in each month. It is not regular. (Sinan)

On the other hand, Feride and Sinan stated that MoNE's policy of employing hourly-paid teachers aims to save from labor expenditures by exploiting reserve workforce ready to accept any disadvantaged condition due to unemployment.

Clearly, the number of teachers that is needed by the government is obvious. They can appoint enough number of teachers to meet that need and then, hourly-paid teaching can be abolished. But they don't do it, they say budget, they say money. As I said, while they pay 6,000 liras to 7,000 liras to the permanent staff, they pay me 1,500 liras. I do the same job. They will lose the money of three hourly-paid teachers if they change my status as permanent. They are saving the money with people like us. They do not do these things, but somehow if I do not do it, if I do not work, someone will come out. There are so many graduate teachers waiting to be appointed. (Feride)

There are many alternatives to your place when you refuse to work. There are associate degree graduates and even if those associate degree graduates refuse, this time high school graduates will take your place. There are no criteria for hourly-paid teachers either. So now, for example, when you do not do it, they also hire an associate degree graduates instead of you and nobody can say anything. (Sinan)

Hourly-paid teachers are paid depending on the number of the lessons they teach. Therefore, their wages are deducted at the times of public holidays. It is clearly seen that what causes Feride to experience economic hardship is the salary deductions. Feride stated that her already low wage is deducted because of situations such as snow holidays or public holidays, and she cannot earn anything during summer vacations when schools are totally closed. She explains this as follows:

How much money are you already paying me? There is a holiday, I do not want that holiday, but you are deducting that holiday from my salary. People are praying for a snow holiday, I pray that it does not snow. There is no guarantee of how much money I get. There is a holiday so you don't want that holiday because your money is deducted. For example, on a public holiday, a permanent teacher is paid, but I am not. I'm already paid a little, they also deduce my money.

Besides the salary deduction, Feride and Sinan's social security premiums are also deducted. As hourlypaid teachers' social security premiums are paid like their wages, Feride and Sinan cannot even plan a retirement like their permanent colleagues. Having difficulties in even their daily livelihoods, Feride and Sinan's pessimism can be understood in their following statements:

Our insurance covers the hours we normally teach. So when you work this way, eight days a month. Ten days maximum. When you teach all the week, the insurance covers only fifteen days. As long as we continue to work in this way, we will never have a chance to retire. I calculated it sometime. I learnt I could retire in 2150. It's already a dream for me. (Sinan)

Teachers of my age have been retiring. I haven't even completed my day to retire yet. Our insurance is not fully paid. My insurance is paid for the number of days I work. I have been a teacher for 20-22 years, but 
in the records it seems I have only worked for ten years. In other words, I haven't even completed 36002 days as premium. Because at first, it wasn't paid at all. Insurance record did not exist. It was said that the pension fund was paid in the first two years, but there are no documents, nothing. Then the computer was not that common, so I don't have any documents about it. I don't know where I can get it from. 4-5 years was not paid at all, we could only benefit from health insurance. After then, our premiums were paid 18 days in one month, 8 days in one month depending on the number of holidays in that month. These conditions are challenging. And it is difficult for a person who supports a family. (Feride)

Feride and Sinan also cannot take advantage of the rights permanent teachers normally use. It is understood from their narratives at the following that both of the participant teachers cannot use the rights such as in-service training, green passport providing visa free travel, and discounts valid at museums or public transportation that are only provided to permanent teachers:

I have entered my sixteenth year and I have still working. I have many friends working at the same school, as well. They came after me. So they have a green passport. They can easily enter everywhere, they can do anything. I have worked four years more than them and I have nothing. (Sinan)

Generally, in-service trainings, seminars, and certificate programs are for permanent teachers. For example, I cannot benefit from discounts. So we use the subway, the money I earn is at most 1,500 TL. The other (permanent teacher) earns 4,000 liras. He pays 1.85 TL for the subway, but I pay 2.65 TL. I'm the one who gets less money, but he's the one (permanent teacher) who gets the discount. For example, I pay full money because I do not have a teacher card to enter a museum. He shows his teacher card and enters some places for free. When we go to the theatre, he is the one (permanent teacher) who benefits from the teacher discount. (Feride)

From time to time Feride experienced bad attitudes sourced from school administrators. Due to her lack of job security, Feride also faced situations where school administrators made her do drudgery, although she was not responsible. Feride narrated what she experienced as below:

In some schools, they were forcing us to come when there was a ceremony. But I don't get paid, so I don't have to come. There are periods of imposition. For example, we were attending the general assembly meeting at the end of the term. The vice principal came and sat on his chair and said that the classes were then empty, the floors were mixed. He said, let's take hourly-paid teachers to the floors, and let them stand guard.

Sinan also felt the discrimination between hourly-paid teachers and permanent teachers at schools where he has worked so far. While Feride was forced to do drudgery, Sinan, on the other hand, experienced discrimination in terms of the weekly schedule. According to Sinan, while preparing the weekly course schedule of the school, the administrators gave priority to the permanent teacher. Below is how Sinan narrated this discrimination against himself.

In the first years, I faced discrimination from administrators. The worst weekly course schedule is prepared for you. The worst classes are given. When you go to school, the educational year has already started. You start working after a week or two, officially. When you go, you see that permanent teachers have taken the best classes. They have got the best weekly course schedule. They also give you such things in between, and unwanted classes. Of course, these are demoralizing.

The difficulties Feride and Sinan experienced in making ends meet obligated them to do extra works. Feride worked at a private teaching institution for three years to earn additional income and make up for the

\footnotetext{
${ }^{2} 3600$ is the number of working days in Turkey needed to be worked to qualify for retirement.
} 
lack of her insurance premiums. Sinan, on the other hand, has been doing different extra jobs since he started hourly-paid teaching. Their narratives on the extra jobs they have done so far are as below:

This job was a little more attractive to me, as there was an additional job opportunity, in terms of time. Otherwise, there is no economic profit. Hourly-paid teaching provided me some spare time to do additional work. For example, I tried to teach science or chemistry lessons in study centers. For a while, I became a business partner in a small cafe. I ran a cafe. I did some work in marketing. In other words, they were jobs similar to our profession. Just running a cafe was a bit different, though. You know, it didn't take much of my time because the cafe was in the Fatih region where I teach as an hourly-paid teacher. In that sense, it felt good, that is, hourly-paid teaching. (Sinan)

Occasionally I worked in a private teaching institution and completed my missing social security payments. I worked there for three years. It was very tiring. Since I made an extra effort not to reduce that efficiency, I was very tired and worn out at that time. It was one of my friendss institution. The students there were also students from my old school. I didn't have much trouble there either. Running around was a little tiring for me in terms of time. The rush tired me. Then classes at this school were starting in the morning. We started the lessons at 07.20 a.m. and ended at 12.30 p.m. My lesson was starting there at $13.30 \mathrm{pm}$. There was only an hour in between. I had to be there until 19:00 pm. When I came home, I was already sleeping. I had nothing else to do. I was working on the weekends. I was working on Saturday, a full day. It was like this in the first year. In the second year, I said, I cannot stand it under those conditions, I want to quit. He didn't want me to quit either. He said, let's only give you eighth-graders at least, and let's organize the working days as you wish. We agreed on two days a week plus the weekends. In the third year, I decided to quit completely. This time he insisted me to only teach eighth-graders one day in a week. I worked like that for the last year. However, I like the school environment more. I don't know, maybe it's because of the atmosphere, but I feel like a teacher here. There is a situation that seems to serve the private educational institution owner rather than the child because it also carries a commercial concern. (Feride)

Factors such as impermanence, uncertainty, low salaries, insecurity and future anxiety, which are characteristic of hourly-paid teaching, cause individuals to continue their lives under these conditions. In other words, hourly-paid teachers have to put off most of their life decisions and give up their future dreams due to their uncertain conditions. For example, it can be understood from Sinan's narrative below that he is not able to make a life plan and get married.

You do not have the right to marry when you are an hourly- paid teacher. Because the money you earn is insufficient. You know, the female teachers teaching here prefer the permanent staff to secure their lives. That's why I have still not married anyway. I am thirty-eight years old. Staying single until this age is entirely due to working as an hourly- paid teaching. So, your life always stays behind like this. So, you cannot make any plans in any way.

\section{Meaning of the Profession}

Under the fact that Feride continued hourly-paid teaching under unfavorable economic and social conditions lies her love and commitment to the teaching profession. Feride's narrative at the following emphasizes that she loves her job despite the conditions explain the reasons why she has continued hourlypaid teaching for more than twenty years:

So I keep going like this whenever I can. Or as long as I am needed as an hourly-paid teacher. I cannot do any other work. Especially after this time, after this age... I also don't want to do another job. Now I am 3 months off. No salary, nothing. I'm unemployed. But I love this job, I enjoy it. So even when I'm talking to you, I can get nervous right now. But I am very comfortable with the students. In other words, when an actor appears on the stage, he will be happy like that. I feel that way when I am with children, when I enter 
the classroom. One should love first of all. It is really not a job to do without loving. If I continue to do this even under the conditions of hourly-paid teaching, I do it because I really love it, otherwise it is not really a good under these conditions. The conditions for hourly-paid teaching are very bad.

Feride drew attention to the unfavorable economic and social conditions of hourly-paid teaching and emphasized that she has been pursuing this profession for years despite these conditions. On the other hand, Sinan emphasized the student profile of the schools where he has worked so far as well as the economic and social conditions of hourly-paid teaching. Sinan stated that he has had to work at the school where disadvantaged students enroll in and normally permanent teachers do not want to teach. His narrative on this issue is as follows:

I did not work in very good schools. In other words, I worked in problematic vocational high schools and mediocre schools where permanent teachers normally don't want to go. I mainly worked in regions with low-income levels of students. That's why I haven't had the opportunity to work in high-level schools. Teachers did not prefer this school because it was in a region of immigrants. Teachers stayed for a year at most and found a way to escape. For example, I have been working at this school for eleven years. Any science teacher has not been appointed here for eleven years although there is shortage. Somehow, they try to escape from that area. But I also worked in a good Anatolian high school for a year or two. Of course, working with good students is always enjoyable.

Even though she was working under bad conditions, her passion for the teaching profession pushed Feride to do many extra activities without any charge because she thought it would be in the interest of her students. The inner satisfaction stemming from the feedback she got from her old or current students and student parents seems to have made up to some extent for the economic and social conditions of hourly-paid teaching. Feride narrated the inner satisfaction she got from teaching as follows:

I'm trying to look from the children's perspective. For example, I put out a dance show with sixth graders on April the 23rd. We performed the same dance show as a year-end show. That's why I stayed with those kids for two more hours every Monday. Those are extra stuff for me. I enjoyed it and the happiness of the children is really... We prepared for this show for April the 23rd. But It was not enough for me, and we continued as an end-of-year show for two more months. I mean, it's tiring, but the happiness of those children and the fact that something beautiful has come out makes me happy. That's why I also get criticism from some of my friends. They asked, why I was tiring yourself so much with so much dedication. But this is not a cause of wear for me. I'm getting happy. So my situation may not reflect other hourly-paid teachers. Because for me, this is really a matter of heart. I do it really fondly. It's really not a job to do for money or anything. I have no obligation. I do not have to give extra courses. It will be a bit cheesy, but there are those who see me as a fool. While the permanent teacher gets 4,000-5,000 Turkish liras, he does not do this and does not work that much. There are those who say why I am doing it even though you don't get your money. But for me it's not work, just life.

Like Feride, Sinan also emphasized the inner satisfaction he gets from the teaching profession. On the other hand, the inner satisfaction Sinan gets sourced from making a positive contribution to the lives of disadvantaged students in his region. Sinan's narrative who tries to save students who have got involved in criminal activity is as follows:

Since these children are immigrants, they were doing things like bad habits, drug dealing, and snatching in that area. We motivated these students to the school. We visited their families. There was a sense of respect for me in the students when I visited their families. For example, a student who came out of prison bent over and kissed my hand and told me that he would no longer do that job. When you tell that student that what he did is wrong, when you speak the same language as that student, you also keep the student 
from those bad habits. That student also trusts you. I constantly meet with families. They are clever kids as well. There is only the impossibility. They can't find the fees to go to a private teaching institution anyway. They are constantly forced to earn money by their families. They don't even have the money to buy books. I know it isn't true, but we copy books and give them to those students. To make it cheaper. Or we buy books by paying our own pocket.. Why? To let the child cling to life.

Since both of them work in schools in the regions where disadvantaged students live, their effects on their students' lives enabled Feride and Sinan to pursue hourly-paid teaching for many years. At this point, the feedback they got from both students and student parents provided Feride and Sinan the motivation they needed. The prominent point in Feride's narrative was the contribution she made to students' academic achievement as a teacher. On the other hand, Sinan emphasized the support he gave to students who are unsuccessful due to the economic conditions. Narratives of both of the teachers are as follows:

Parents of my old students still call me sometimes. They ask my opinion because they will make a university choice this year. What shall we do? Suggest us. They graduated years ago, but they still call me and ask for suggetions. In our school, there are students who are extreme points in terms of economic conditions. On the other hand, there are also successful students at our school. One of our graduates has become a judge, another has become a medical doctor. We also have students who are currently studying medicine. They are rare, but we can catch them as well. When we catch and train them individually, there are, for example, students who have got accepted into medical faculty and are now in the fourth grade. There are those who have studied law and have been appointed as a judge. He came to visit the other day. Every year, for example, let's say I put students in the scholarship exam, and three of them earn the scholarship. Next year my goal is to help six students. Last year, we helped nearly thirty students to earn the scholarship. It is a small amount such as 250-300 Turkish lira a month, and it is not cut until the eighth grade. But if you see the happiness of those families, believe me, it seems like I will work for another fifteen years. (Sinan)

I had hesitations before now. I asked myself if I am enough, but I know I am. Last year we sent a student to Çapa Science High School. We sent another one to Şehremini High School. We sent a student to Istanbul Erkek High School. One of our students may pass Çapa Science High School this year. Those who passed to Çapa Science High School and Şehremini High School are twins. It's been a month or so since their mother visited me. The woman almost kissed my hands. She said, "I pray for you every day". She also said at Çapa Science High School, there are students coming from colleges whose English is very good. My twins aren't noticed among all those students. One of them even took second place. The girl was also very good at English. Did you take lessons? They were constantly asking them how they are so good at English. We pray to you every day, the mother said. [...] The school administration was also aware of this situation. For example, parents who had strong communication with the administration went to the headmaster and asked me for their children's classroom as a teacher. It happened in one of my old schools. There were classes that I had to leave because a permanent teacher was appointed in the middle of the academic term, for example, students wandered after me crying for days. The parents stormed the administration and asked why they took me from their classroom. This means I am doing something right. (Feride)

Feedback Feride and Sinan get from their students and student parents not only motivates them but also let them develop a self-efficacy belief. Feride and Sinan, having been doing their jobs under economically and socially hard conditions, consider themselves successful teachers. Furthermore, the experience they have gained in long years also consolidates Feride and Sinan's belief that their teaching practices are successful. Their self-efficacy beliefs are reflected in their narratives below:

Now I believe I do it well. There was distrust at first, wondering if I could do this job. But now I believe that I'm doing good. As I said, I am very lucky in this regard that my administrators have always stood behind me. After observing me for a while in my old school, they sum it up. They were asking me about the 
exam results that, for example, how a child whose success was crawling on the floor on other lessons was good at English exams. Or there were friends who asked me how to do it if there was something wrong. I proved myself, but when did it happen? I do not remember exactly how it happened. This year, many things that I said will be on the exam came out in the exam. (Feride)

It is something that has been brought about by working for years now. I do not make a distinction as permanent or -hourly paid, but I have no shortcomings in my field. Plus, even newly-appointed teachers get my advice. I guide them. In this sense, this brought respectability to me. This may be because I have been working for many years, but I think that when you do your job well and give your due, you gain respect everywhere. (Sinan)

\section{Discussion and Conclusion}

The most important concept that reflects the life and existence style of the neoliberal age is flexibility and temporality. In this age when social securities have been disappearing one by one, flexible and temporary employment has become a norm in labor markets. Even in the public sector, employments are made on temporary and flexible contracts and the teaching profession is not an exception to this flexibility. In this context, this study focused on hourly-paid teaching which is one of the oldest types of flexible employment in the public sector and aimed at analyzing the narratives of two hourly-paid teachers, Feride and Sinan, who have been teaching under flexible contracts for more than fifteen years.

The narratives of two hourly-paid teachers have common aspects as well as different ones. Both Feride and Sinan chose hourly-paid teaching due to economic conditions and unemployment. As a matter of fact, it is possible to observe findings supporting this idea in the related literature. Both Sağıroğlu's (2013) and Güvercin's (2014) study also revealed that teachers applied for hourly-paid teaching temporarily until they find a permanent job. Similarly, Yayla et. al. (2018) and Günerigök and Oğur (2018) obtained that the majority of hourly-paid teachers preferred this job due to unemployment.

Both Feride, who started hourly-paid teaching while she was a high school graduate, and Sinan, who started the profession holding an undergraduate degree in chemistry without any formal education in teaching have acquired teaching skills by observing more experienced teachers. Thus, both teachers have become experienced teachers over the years. Karataş and Karaman's (2013) research revealed findings similar to Feride and Sinan's narratives. According to the study, one of the approaches utilized by inexperienced teachers to learn instructional strategies is to observe teachers who are more experienced than them.

Although Feride and Sinan started their profession for similar reasons, there are different reasons behind their pursuing hourly-paid teaching for many years. The bond Feride constructed with her students and the teaching profession has caused her to refuse more appealing job offers she had encountered in time. Sinan, on the other hand, continued to work as an hourly-paid teacher for sixteen years as this job provided him the opportunity to do different jobs and during this period, he had to do different jobs besides teaching.

This necessity that Sinan experienced stems from the fact that temporariness of hourly-paid teaching dominates his whole life, and Feride is not an exception. Both teachers feel anxiety and uneasiness due to the fact that hourly-paid teacher's contracts are valid for only one educational year. Besides being employed for a temporary period, Feride and Sinan face difficulties in making ends meet as they are paid on an hourly basis rather than a fixed salary. Since their salaries are deducted during periods when classes are not held, such as public holidays, they are paid one-third of permanent teachers' salaries, and their social security premiums are also paid for the day they work. Therefore, Feride and Sinan work temporarily without social security for very low wages, and they cannot dream of retirement or marriage. Sağıroğlu (2013) reached a similar finding and found hourly-paid teachers live an insecure life under social and economic pressures and postpone their plans for the future until they get a permanent job. In addition, there are various studies revealing that hourly- 
paid teachers experience stress, anxiety, and uneasiness due to low wages (Bayram, 2009; Doğan, Demir, \& Turan, 2013; Günerigök \& Oğur, 2018; Öğülmüş, 2012; Turhan, 2011; Yayla, Sak, Şahin-Sak, \& Taşkın, 2018; Yilmaz, 2018).

Although they do the same job as permanent teachers, Feride and Sinan sometimes face discrimination as a consequence of their status. As they are employed temporarily, Feride and Sinan are not able to make use of facilities provided to permanent teachers such as in-service training, green passport, or discounts valid at museums and theatres and public transportation. Similarly, Günerigök and Oğur (2018) revealed in their study that one of the points emphasized by hourly-paid teachers is not being able to benefit from the rights provided to permanent teachers. In addition, the administrators of the schools they have worked in have sometimes exhibited a discriminatory attitude towards Feride and Sinan. Öztaş (2010) also found in her study that hourly-paid teachers are discriminated against by school administrators, permanent teachers, and parents. In another research, Polat (2013) found that school administrators force hourly-paid teachers to do the drudgery. In Tuncer's (2012) study, it was found that school administrators and permanent teachers exhibit discriminatory attitudes towards hourly-paid teachers.

Despite its poor conditions, the teaching profession has a special meaning in Feride and Sinan's lives. They make up for these poor conditions of hourly-paid teaching with the inner satisfaction they get from their jobs. Sinan, in particular, works in a region where internal migration students are concentrated and some of these students are involved in crime, so he obtains great inner satisfaction from contributing to the lives and academic success of his students. Feride, who works in a region with a low socioeconomic level, achieves this satisfaction due to the positive contribution she makes to her students' social development as well as their academic success. On the other hand, Ömür's (2018) findings show that Feride and Sinan's inner satisfaction they get from teaching may be explained by the epistemological authority which teachers working with low socioeconomic level students have against student parents. In the study, the researcher found that teachers working with students from low socioeconomic levels get more satisfaction from their jobs because they have more power over students and student parents. Similarly, Tamir (2009) found that graduates of Ivy League Universities choose to teach in low socioeconomic regions because of the same reason. Findings of Byrd-Blake et. al. (2010) also support Feride and Sinan's narratives. In that study, it was found that teachers get great satisfaction from making a difference in the lives of socioeconomically disadvantaged students.

The factor that motivated Feride and Sinan to pursue hourly-paid teaching for more the fifteen years was the feedback they both get from students and student parents. This motivation, along with the experience they have acquired in long years, let Feride and Sinan develop a self-efficacy belief. As a result, both Feride and Sinan identified themselves as successful teachers.

A similar finding was revealed by Güvercin (2014). In the study, it was found that hourly-paid teachers regard themselves as good teachers as permanent ones, and similar to Feride and Sinan, hourly-paid teachers relate their teaching skills with their personal characteristics. Similarly, Sağıroğlu's (2013) findings revealed that hourly-paid teachers related their characteristic dispositions with their teaching skills. On the other hand, both Feride and Sinan's many years of teaching experience seems to have them develop self-efficacy beliefs. As a matter of fact, Bandura (1994) stated that one of the most effective sources of self-efficacy is the experience of mastery. In the literature, there are also various different studies that reveal teacher self-efficacy belief is closely related to teaching experience (Çoban, Özdemir, \& Bellibaş, 2020; Klassen \& Chiu, 2010; TschannenMoran \& Woolfolk Hoy, 2007; Wolters \& Daugherty, 2007). Any other way, according to Güvercin (2014), another reason lies behind the effort and devotion hourly-paid teachers exhibit. In the study, it was found that hourly-paid teachers feel obliged to prove their teaching skills to school administrators, student parents, other teachers, and students because they feel the stress of not being employed next year. 
However, it is seen that Sinan continues his teaching profession due to the positive behavior change and academic success in the students. This situation shows that both teachers have an intrinsic and altruistic motivation such as moral satisfaction, contribution to the student, school and society, beyond continuing their teaching profession with the expectation of an external motivation such as reward or salary expectation. Similarly, in studies on teacher motivation, it is seen that sincere and altruistic motivation plays an important role in choosing and maintaining the teaching profession. (Akar, 2012; Dündar, 2014; Ertürk, 2016; Kılcan, Keçe, Çepni, \& Kılınç, 2014; Kılınç, Watt, \& Richardson, 2012; Topkaya \& Uztosun, 2012; Toraman, Özdemir, \& Orakc1, 2020). 


\section{REFERENCES}

Akar, E. O. (2012). Motivations of Turkish pre-service teachers to choose teaching as a career. Australian Journal of Teacher Education, 37(10), 67-84.

Bandura, A. (1994). Self-efficacy. In V. Ramachaudran (Ed.), Encyclopedia of human behavior (pp. 71-81). New York: Academic Press.

Bayram, G. (2009). Öğretmenlerin istihdam biçimi farklılıkları ve yarattı̆̆ı sorunlar: Ankara'da çalışan sözleşmeli ve ücretli öğretmenlerin görüşlerine dayalı bir araştırma. (Unpublished master's thesis). Ankara University, Institute of Educational Sciences, Ankara.

Bryman, A. (2016). Social research methods. Oxford: Oxford University Press.

Byrd-Blake, M., Afolayan, M. O., Hunt, J. W., Fabunmi, M., Pryor, B. W., \& Leander, R. (2010). Morale of teachers in high poverty schools: A post-NCLB mixed method analysis. Education and Urban Society, $42(4), 450-472$.

Connelly, F. M., \& Clandinin, D. J. (1990). Stories of experience and narrative inquiry. Educational Researcher, 19(5), 2-14.

Creswell, J. W. (2012). Qualitative inquiry and research design: Choosing among five traditions. Thousand Oaks, CA: Sage.

Crowley, M., \& Hodson, R. (2014). Neoliberalism at work. Social Currents, 1(1), 91-108.

Çınkır, Ş., \& Kurum, G. (2017). Atanmak ya da atanamamak: Ücretli öğretmenlerin yaşadıkları sorunlar. Eğitimde Nitel Araştırmalar Dergisi, 5(3), 9-35.

Çoban, Ö., Özdemir, N., \& Bellibaş, M. Ş. (2020). Trust in Principals, Leaders' Focus on Instruction, Teacher Collaboration, and Teacher Self-Efficacy: Testing a Multilevel Mediation Mode. Educational Management Administration \& Leadership, 1-18.

Doğan, S., Demir, S. B., \& Turan, N. (2013). Ücretli öğretmenlik uygulamasının değerlendirilmesi. Turkish Studies, 8(12), 371-390.

Dündar, Ş. (2014). Reasons for choosing the teaching profession and beliefs about teaching: A study with elementary school teacher candidates. College Student Journal, 48(3), 445-460.

Ertürk, R. (2016). Öğretmenlerin iş motivasyonları. Eğitim Kuram ve Uygulama Araştırmaları Dergisi, 2(3), 1-15.

Golafshani, N. (2003). Understanding reliability and validity in qualitative research. The Qualitative Report, $8(4), 597-607$.

Günerigök, M., \& Oğur, K. (2018). Prekarya sosyolojisi: Ücretli öğretmenler örneği. Din ve Bilim - Muş Alparslan Üniversitesi İslami İlimler Fakültesi Dergisi, 1(2), 138-156.

Güvercin, G. (2014). Informal workplace practices and learning experiences of permanent and hourly-paid teachers: A comparative study. (Unpublished doctoral dissertation). Boğaziçi University, Graduate Studies in the Social Sciences, Istanbul.

Huberman, A. M., Miles, M., \& Saldana, J. (2013). Qualitative data analysis: A methods sourcebook. (3 ${ }^{\text {rd }}$ Edition). Thousand Oaks, CA: Sage.

Karataş, P., \& Karaman, C. (2013). Challenges faced by novice language teachers: Support, identity, and pedagogy in the initial years of teaching. The International Journal of Research in Teacher Education, 4(3), $10-23$.

Kelchtermans, G. (1993). Getting the story, understanding the lives: From career stories to teachers' professional development. Teaching and Teacher Education, 9(5-6), 443-456.

Kılcan, B., Keçe, M., Çepni, O., \& Kılınç, A. Ç. (2014). Prospective Teachers' Reasons for Choosing Teaching as a Profession. Kastamonu Education Journal, 22(1), 69-80. 
Kılınç, A., Watt, H. M., \& Richardson, P. W. (2012). Factors influencing teaching choice in Turkey. Asia-Pacific Journal of Teacher Education, 40(3), 199-226.

Klassen, R. M., \& Chiu, M. M. (2010). Effects on teachers' self-efficacy and job satisfaction: Teacher gender, years of experience, and job stress. Journal of Educational Psychology, 102(3), 741-756.

Lincoln, Y., \& Guba, E. (1985). Naturalistic inquiry. Beverly Hills, CA: Sage.

Merriam, S. B. (2002). Qualitative research in practice: Examples for discussion and analysis . In S. B. Merriam (Ed.), Introduction to qualitative research (pp. 3-17). San Francisco, CA: Jossey-Bass.

Ministry of National Education. (1973). Milli Egitim Temel Kanunu.

Ministry of National Education. (2020). 2020-2021 Eğitim-Öğretim Yılı İçin Ek Ders Karşıllı̆g Ü Ücretli Öğretmen Görevlendirme Duyurusu.

Mishler, E. G. (1995). Models of narrative analysis: A typology. Journal of Narrative and Life History, 5(2), 87-123.

Orakc1, Ş. (2015). Şangay, Hong Kong, Singapur, Japonya ve Güney Kore'nin öğretmen yetiştirme sistemleri'nin incelenmesi. Asya Öğretim Dergisi, 3(2), 64-76.

Öğülmüş, K. (2012). Ücretli öğretmenlerin görevlerini yaparken karşılaştıkları sorunlar ve ücretli öğretmenlik uygulamasının okul yöneticilerince değerlendirilmesi. (Unpublished master's thesis). Gaziosmanpaşa University, Institute of Social Sciences, Tokat.

Öğ̈̈lmüş, K., Yildirim, N., \& Aslan, G. (2013). Ücretli öğretmenlerin görevlerini yaparken karşılaştıkları sorunlar ve ücretli öğretmenlik uygulamasının okul yöneticilerince değerlendirilmesi. İlkogretim Online, 12(4).

Ömür, Y. E. (2018). Teaching the poor: A phenomenological insight. International Journal of Progressive Education, 14(2), 208.

Öztaş, S. (2010). Kadrolu, sözleşmeli ve ücretli statüye göre öğretmenlerin mesleki aidiyet duygusunun değerlendirilmesi (Antalya ili, Alanya ilçesi ilköğretim okulları örneği). (Unpublished master's thesis). Ankara: Gazi University, Institue of Educational Sciences.

Patton, M. Q. (1990). Qualitative evaluation and research methods. Newbury Parl, CA: Sage.

Polat, S. (2013). Ücretli öğretmen istihdamının yarattı̆̆ı sorunlar üzerine nitel bir araştırma. Mehmet Akif Ersoy Üniversitesi Ĕ̆itim Fakültesi Dergisi, (28), 67-88.

Reissman, C. K. (1993). Narrative analysis. California: Sage.

Rosenthal, G. (2004). Biographical research. In C. Seale, G. Gobo, J. Gubrium, \& D. Silverman (Eds.), Qualitative Research Practice (pp. 48-65). London: Sage.

Sağıroğlu, S. (2013). From precarious employment to precarious life: The case of non-appointed teachers in Turkey. (Unpublished master's thesis). Middle East Technical University, Graduate School of Social Sciences, Ankara.

Saldaña, J. (2012). Coding manual for qualitative research. London: Sage.

Schleicher, A. (2018). World class: How to build a 21st century school system, strong performers and successful reformers in education. Paris: OECD Publishing.

Standing, G. (2011). The precariat: The new dangerous class. New York: Bloomsbury Academic.

Tamir, E. (2009). Choosing to teach in urban schools among graduates of elite colleges. Urban Education, 44(5), 522-544.

Topkaya, E. Z., \& Uztosun, M. S. (2012). Choosing teaching as a career: Motivations of pre-service English teachers in Turkey. Journal of Language Teaching and Research, 3(1), 126.

Toraman Ç., Özdemir H.F., \& Orakc1, Ş. (2020). Experiences of Turkish teachers working abroad. SAGE OPEN, 10(1), 1-9. 
Tschannen-Moran, M., \& Woolfolk Hoy, A. (2007). The differential antecedents of self-efficacy beliefs of novice and experienced teachers. Teaching and Teacher Education, 23, 944-956.

Tuncer, M. (2012). Türkiye'deki kadrosuz öğretmen istihdamının kadrosuz istihdam edilen öğretmen görüşlerine göre değerlendirilmesi. Gaziantep Üniversitesi Sosyal Bilimler Dergisi, 11(3), 797-818.

Turhan, M. (2011). İlköğretim okullarında görev yapan okul yöneticileri ve öğretmenlerin ücretli öğretmenliğe ilişkin görüşleri. New World Sciences Academy, 6(2), 1775-1785.

Wolters, C. A., \& Daugherty, S. G. (2007). Goal structures and teachers' sense of efficacy: Their relation and association to teaching experience and academic level. Journal of Educational Psychology, 99(1), 181-193.

Yayla, A., Sak, R., Şahin-Sak, İ. T., \& Taşkın, N. (2018). Comparing the job satisfaction of hourly paid and salaried preschool teachers in Turkey. Education, 46(7), 814-824.

Yılmaz, M. (2018). Ücretli öğretmenlerin karşılaştıkları sorunlar. Akdeniz Ĕğitim Araştırmaları Dergisi, 12(25), $102-116$.

Yin, R. K. (2017). Case study research and applications: Design and methods. Thousan Oaks, CA: Sage. 